УдК 343.9

\author{
Є. Д. Лук'янчиков, В. Є. Лук'янчикова
}

\title{
КРИМІНАЛІСТИЧНА ХАРАКТЕРИСТИКА В МЕТОДИЦІ РОЗСЛІДУВАННЯ ОКРЕМИХ КАТЕГОРІЙ ЗЛОЧИНІВ
}

Постановка проблеми. Останніми роками спостерігається постійне зростання злочинності в Україні, відбуваються зміни в ії структурі та характері. За даними офіційної звітності Генеральної прокуратури України, протягом 2016 р. зареєстровано 592,6 тис. кримінальних правопорушень, що на 27,4 тис. більше, ніж у 2015 р. Ще більшими темпами відбувається зростання тяжких та особливо тяжких злочинів (у 2016 р. - 232,5 тис., що на 33,1 тис. більше, ніж у 2015 р.). Упродовж 2016 р. до суду направлено 141392 кримінальні провадження, що на 15,8\% менше, ніж у 2015 р.

Обставини, що негативно впливають на стан злочинності, зумовлені багатьма чинниками. 3 одного боку, це реальні бойові дії на Донбасі й широке розповсюдження різноманітних видів зброї серед населення. За даними окремих дослідників, в обігу перебуває близько 5 млн. одиниць нелегальної вогнепальної зброї. 3 іншого - це реорганізація, що відбувається в слідчих і оперативних підрозділах правоохоронних органів, професійне ядро яких сьогодні розпорошено. У таких умовах постає завдання підвищення професійного рівня слідчих та оперативних співробітників, на яких покладено своєчасне виявлення злочинів, що готуються, документування злочинних дій, формування доказів у процесі кримінальної процесуальної діяльності. Зміни в структурі та характері сучасної злочинності зумовлюють необхідність удосконалення наявних методик розслідування злочинів і розроблення нових. Тільки науково обгрунтована методика дає змогу вирішувати системні завдання повного й достовірного розслідування злочинів. Значне місце в розробленні таких методик належить криміналістичній характеристиці, на основі якої у взаємозв'язку з іншими характеристиками злочину можуть бути побудовані гносеологічні концепції й моделі встановлення істини в кримінальних провадженнях [9, с. 362-363]. Учення про криміналістичну характеристику, зазначають В.Г. Гончаренко та В.Е. Бергер, привертає увагу науковців і практиків. Без неї методика розслідування як розділ науки в певному розумінні втрачає сенс [5, с. 45]. Сьогодні більшість посібників із методики розслідування окремих категорій злочинів починаються з висвітлення загальних питань криміналістичної характеристики й опису її елементів. 
Аналіз останніх досліджень і публікацій. Перші згадки про криміналістичну характеристику зустрічаються в роботах О.Н. Колесніченка та Л.А. Сергєєва [8; 12]. Подальший розвиток учення щодо криміналістичної характеристики супроводжувався активними дискусіями на наукових семінарах і конференціях, висвітлювався в публікаціях В.П. Бахіна, Р.С. Бєлкіна, І.Ф. Герасимова, В.Г. Гончаренка, В.А. Журавля, В.А. Колесника, В.О. Коновалової, М.А. Погорецького, М.В. Салтевського, М.О. Селіванова, В.В. Тіщенка, В.Ю. Шепітька й інших авторів.

Мета статті - проаналізувати поняття криміналістичної характеристики і структуру іï елементів; провести порівняння та зіставлення характеристик злочину, які зустрічаються в наукових дослідженнях.

Виклад основного матеріалу дослідження. Не вдаючись до поглибленого аналізу визначень криміналістичної характеристики, звернемо увагу на загальні ознаки, які в них відображено: а) система узагальнених відомостей про ознаки певного виду злочинів; б) встановлення кореляційних зв'язків між такими даними; в) призначеність для використання в розслідуванні конкретних категорій злочинів.

Криміналістичну характеристику в узагальненому вигляді розглядають як ідеальну модель типових зв'язків і закономірно сформованих джерел доказової інформації, яка дає можливість прогнозувати оптимальний шлях і найбільш ефективні засоби розслідування окремих видів злочинів. Із криміналістичного погляду будь-яка розслідувана подія (злочин) являе собою інформаційну модель певного класу, що піддається достатньо точній діагностиці, а отже, алгоритмізації та прогнозу розслідування. Іншими словами, знання зазначеної інформаційної структури зумовлює стратегію пошуку істини й тактику доказування [9, с. 363].

Злочин є об'єктом дослідження багатьох наук, кожна з яких намагається вивчити та описати його соціальний, кримінально-правовий, кримінологічний, морально-етичний, криміналістичний, психологічний та інші аспекти, з метою подальшого використання таких відомостей для розкриття, розслідування злочинів і запобігання їм. Кожна з них досліджує ті елементи й ознаки злочину, що належать до ії предмета, акцентує увагу на найбільш суттєвих рисах цього суспільно небезпечного соціального явища.

У криміналістичній характеристиці опису підлягають ознаки, що мають саме криміналістичне значення, сприяють підвищенню ефективності роботи з розкриття злочинів. Проте це не виключає можливості використовувати для побудови методик розслідування відомості про ознаки злочину, що містяться в інших характеристиках. Використанню кримінологічних даних з метою розкриття конкретного виду злочинів присвячено самостійне наукове дослідження. Це є наочним свідченням того, як накопичений матеріал однієї галузі знань використовується іншою для розроблення ефективних методик розслідування [4].

Тривалий час для розроблення методичних рекомендацій із розслідування злочинів використовували відомості кримінально-правової та кримінологічної характеристик, що неповною мірою задовольняло потреби 
практики. Перед науковцями постало завдання розробити методики, що будуть ураховувати відомості про ті ознаками злочину, які мали важливе криміналістичне значення, сприяли результативності розслідування.

Більше ніж двадцять років тому зроблено спробу розробити альтернативу поняттю «криміналістична характеристика злочинів» і замінити його поняттям «типові інформаційні моделі злочинної діяльності». На слушну думку Г.К. Захарова, поняття «криміналістична характеристика» широко використовується в навчальній літературі, не вичерпало своїх можливостей, а тому навряд чи потребує запропонованої заміни [7, с. 167-174].

Криміналістична характеристика як кримінально-правова та кримінологічна категорія містить інформацію про злочин загалом, а також складові його елементи (об’єкт та об’єктивну сторону, суб'єкта й суб'єктивну сторону). На відміну від них, вона являє собою, по-перше, систему тільки криміналістично значимих відомостей про ознаки злочину, а не будь-яких однакових для всіх видів злочинів. По-друге, відомості про ознаки елементів злочину підлягають опису на якісно-кількісному рівні з визначенням кореляційних залежностей між ними, що підвищує практичне значення цієї категорії криміналістики.

Зважаючи на те, що в криміналістичній характеристиці мають відображуватися відомості тільки про ознаки злочину, сумнівним уважається описування в ній тих обставин, що безпосередньо злочину не стосуються, хоча й впливають на організацію роботи з його розслідування. До них інколи зараховують вихідні дані на початок розслідування, що мають значення для висування версій [2, с. 312], характеристику типових ситуацій цього виду злочинів [11, с. 9-10], умови охорони предмета злочинного посягання [13, с. 92], описування стану й особливостей боротьби з різними категоріями злочинних дій (поняття цього виду злочинів, послідовність, строки розслідування, стан і значення боротьби з окремими видами злочинів), стан виявлення причин та умов, що становлять детермінаційний комплекс обставин, які породили й зумовили злочинність в установах виконання покарань [6, с. 266], тощо.

Дослідники по-різному підходять до визначення елементів (структури) криміналістичної характеристики. Слушно зазначає В.В. Тіщенко, що це пояснюється відсутністю єдиного критерію для їх виділення, і пропонує дотримуватися двох умов. Перша - набір елементів має бути системним, що забезпечує повноцінне функціонування розглядуваного поняття й відбиває основні закономірності в механізмі такого функціонування.

Друга - виділені елементи повинні мати здатність нести інформацію про зміст і значення слідів-відображень і механізм їх утворення, відбивати можливості побудови моделі події загалом чи окремих іï елементів в умовах дефіциту інформації, щодо окремих обставин, особливостей взаємозв'язку й відносин між ними, показувати, отже, шляхи та засоби пізнання розслідуваної події [14, с. 59].

Інколи в криміналістичній характеристиці намагаються виділити окремим елементом певні обставини, що є характерними для цієї категорії злочинів. 
Проте їх аналіз засвідчує, що мова йде про виділення й описування чотирьох сторін злочину: а) предмет безпосереднього посягання; б) спосіб учинення злочину в широкому розумінні; в) типову обстановку - «слідову картину» в широкій інтерпретації; г) особу злочинця. Відомості про типові елементи криміналістичної характеристики можуть набувати відмінної інтерпретації залежно від конкретного виду злочинів, слушно зазначає В.І. Бояров, досліджуючи злочини екстремістського спрямування [3, с. 32-33].

Погоджуючись із подібним підходом до визначення структури криміналістичної характеристики, не можна залишити без уваги думку Р.С. Бєлкіна щодо недоцільності виокремлювати самостійними елементами спосіб вчинення злочину та слідову картину. Описування способів учинення i приховування злочинів полягає не тільки в описуванні дії чи бездіяльності, за допомогою яких досягають мету посягання, а й в описуванні типових наслідків застосування того або іншого способу, тобто залишених слідів його застосування та місць, які ймовірно можуть бути виявлені. «Голе» описування способу вчинення злочину не досягає мети, його варто проводити або від слідів застосування цього способу з тим, щоб за ними розкривати механізм злочину, або до слідів застосування цього способу, щоб, користуючись відомостями про нього, зуміти виявити докази вчиненого злочину та встановити злочинця [2, с. 314].

Подальша практика розслідування злочинів і розроблення окремих методик розслідування свідчать про доцільність самостійного розгляду таких елементів криміналістичної характеристики, як спосіб злочину та слідова картина. Необхідність розглядати спосіб злочину у зв'язку зі слідами, які ним утворюються, не викликає заперечень. Починається розслідування саме з вивчення слідової картини конкретного злочину та порівняння іï з типовою, що відображена в криміналістичній характеристиці. За слідовою картиною є можливість висунути версії про можливі способи злочину, усвідомити, які й де потрібно шукати додаткові сліди, щоб підтвердити або спростувати висунуті версії. Між способами вчинення злочинів і слідами, які при цьому утворюються, існують певні кореляційні залежності, як i між іншими елементами криміналістичної характеристики, а тому нехтувати ними недоцільно.

Розкриття злочинів забезпечується поєднанням можливостей двох видів діяльності: кримінально-процесуальної та оперативно-розшукової. Актуальність цього питання не втрачає свого значення й в умовах доповнення кримінально-процесуальних засобів пізнавальної діяльності інститутом негласних слідчих (розшукових) дій, які за своєю сутністю, прийомами, методами та суб'єктами іх проведення наближаються до оперативно-розшукових заходів. На цій підставі окремі науковці вважають, що відбулося часткове злиття кримінально-процесуального та оперативно-розшукового законодавства [15, с. 107].

Такий висновок уважаємо передчасним. Це два види державної діяльності з виявлення й розкриття злочинів. Кожний із них урегульовано самостійними законами. Мабуть, саме тому мова завжди йде про дотримання 
процесуальної форми як гарантії законності та обгрунтованості дій і процесуальних рішень у процесі кримінального провадження. Застосування подібних методів пізнавальної діяльності (опитування, спостереження тощо) не може бути свідченням злиття цих видів діяльності щодо боротьби зі злочинністю.

Зважаючи на те, що в розкритті злочинів значне місце належить оперативно-розшуковій діяльності, науковцями цієї галузі зроблена спроба розробити власну характеристику злочинів. Це зумовлено намаганням розкрити ті сторони, риси, ознаки злочину, що не набули відображення в інших характеристиках і мають суттєве значення для розробки рекомендацій із виявлення, розкриття злочинів і запобігання їм саме оперативно-розшуковими силами, засобами й методами.

Так, I.I. Басецький розглядає цю характеристику як науково-практичний термін, що «позначає сукупність специфічних ознак, притаманних як злочинності загалом, так і окремим видам і конкретним злочинам, що використовуються для розробки рекомендацій, спрямованих на прийняття ефективних управлінських та оперативно-тактичних рішень» [1, с. 37].

Виходячи із загального уявлення про характеристику, зазначимо таке: а) у ній мають описуватися відмінні якості, властивості, ознаки злочину. Як самостійний інститут теорії оперативно-розшукової діяльності вона має володіти набором характерних властивостей, які лише в сукупності можуть сформувати критерії для визначення цього поняття, на що звертає увагу більшість науковців. Разом із тим автори не показують, якими мають бути ці відомості; б) в оперативно-тактичній характеристиці виду злочинів мають міститися відомості лише про злочин. Відомості про стан оперативної обстановки в регіоні, стан боротьби зі злочинністю тощо характеризують не сам злочин, а стан і умови роботи з його розкриття.

Натепер будь-яких ознак злочину оперативно-тактичного характеру не виявлено. Для побудови цієї характеристики використовують елементи й ознаки злочину, достатньою мірою досліджені та описані в інших характеристиках. Наближеною до оперативно-розшукової діяльності вважаємо криміналістичну характеристику, використання якої певною мірою може задовольнити як потреби науковців під час розробки рекомендацій із розслідування злочинів, так і оперативних працівників, які застосовують ці рекомендації для розкриття злочинів специфічними засобами й методами.

Визначаючи предмет теорії оперативно-розшукової діяльності як самостійної галузі наукових знань, В.А. Лукашов разом з іншими зараховує до нього правові, кримінологічні та криміналістичні аспекти [10, с. 90-91]. Цю думку поділяють й інші автори, які до предмета науки зараховують практику боротьби зі злочинністю з використанням оперативно-розшукових сил, засобів і методів; правові основи оперативно-розшукової діяльності; систему правових та інших відносин, що виникають у процесі застосування зазначених сил, засобів і методів.

Висновки. Отже, безпосередньо злочин не $є$ предметом теорії оперативно-розшукової діяльності, але всі його елементи й ознаки різною мірою 
сприяють установленню обставин його вчинення й передусім причетної до цього особи. При цьому широко та комплексно використовуються відомості характеристик злочину, що розроблені іншими галузями юридичної науки.

На завершення варто зазначити, що розроблення сучасних криміналістичних методик розслідування має здійснюватися з урахуванням криміналістичної характеристики певної категорії злочинів, яка містить у собі інтегровані відомості сучасних інформаційних систем як про якісні ознаки злочинів, так і про кореляційні зв'язки між ії елементами.

\section{Література}

1. Басецкий И.И. Словарь оперативно-розыскных терминов / И.И. Басецкий, Г.Н. Кабанов, В.П. Шиенок. - Мн. : Академия МВД РБ, 1993. - 45 с.

2. Белкин Р.С. Курс криминалистики : в 3 т. / Р.С. Белкин. - М : Юристъ, 1997. - Т. 3 : Криминалистические средства, приемы и рекомендации. - 1997. - 480 с.

3. Бояров В.І. Щодо криміналістичної характеристики злочинів екстремістського спрямування / В.І. Бояров / / Кримінальне провадження: новації процесуальної теорії та криміналістичної практики : матеріали Міжнародної науково-практичної конференції. 18-19 квітня 2013 року, м. Сімферополь-Алушта. - Сімферополь : ДІАЙПІ, 2013. - С. 32-33.

4. Вайнагий И.И. Использование криминологических данных в раскрытии преступлений, совершаемых в отношении иностранных граждан (по материалам Украины) : дисс. ... канд. юрид. наук : спец. 12.00.09 / И.И. Вайнагий. - К., 1992. - 296 с.

5. Гончаренко В.И. Криминалистика и криминалисты / В.И. Гончаренко, В.Е. Бергер. - К. : Вища шк., 1989. - 128 с.

6. Джужа О.М. Про деякі особливості реалізації на практиці криміналістичної характеристики злочинів, що вчиняються засудженими в ході відбування покарання у виді позбавлення волі / O.M. Джужа, І.О. Колб / / Актуальні питання реформування правової системи : зб. матеріалів XIII Міжнар. наук.-практ. конф. (Луцьк, 24-25 червня 2016 р.). - Луцьк : Вежа-Друк, 2016. - C. 265-267.

7. Захаров Г.К. Новый учебник по криминалистике - новый материал для дискуссии / Г.К. Захаров / / Ученые-криминалисты и их роль в совершенствовании научных основ уголовного судопроизводства : матер. вузов. юбил. науч.-прак. конф. (к 85-летию со дня рождения Р.С. Белкина) : в 2 ч. - М. : Академия управления МВД России, 2007. - Ч. 1. - 2007. - С. 167-174.

8. Колесниченко А.Н. Научные и правовые основы расследования отдельных видов преступлений : автореф. дисс. ... докт. юрид. наук : спец. 12.00.09 / А.Н. Колесниченко. - Харьков, 1967. - 42 с.

9. Криміналістика. Академічний курс : [підручник] / [Т.В. Варфоломеєва, В.Г. Гончаренко, B.I. Бояров та ін.]. - К. : Юрінком Інтер, 2011. - 504 с.

10. Лукашов В.А. Оперативно-розыскная деятельность органов внутренних дел: Введение в курс / В.А. Лукашов. - К. : КВШ МВД СССР, 1976. - 172 с.

11. Пантелеев И.Ф. Методика расследования преступлений : [учебное пособие] / И.Ф. Пантелеев. - М. : ВЮЗИ, 1975. - 46 с.

12. Сергеев Л.А. Расследование и предупреждение хищений, совершаемых при производстве строительных работ : автореф. дисс. ... канд. юрид. наук : спец. 12.00 .09 / Л.А. Сергеев. M., 1966. -24 c.

13. Танасевич В.Г. Теоретические основы методики расследования преступлений / В.Г. Танасевич // Сов. государство и право. - 1977. - № 6. - С. 88-96.

14. Тіщенко В.В. Теоретичні і практичні основи методики розслідування злочинів : [монографія] / В.В. Тіщенко. - Одеса : Фенікс, 2007. - 260 с.

15. Ходанович В.О. Проведення негласних процесуальних дій за кримінально-процесуальним законодавством Німеччини, Швейцарії та Франції / В.О. Ходанович / / Вісник Академії адвокатури України. - К. : ВЦ Акад. адвокатури України, 2016. - Т. 13. - № 3(37). C. $106-114$. 


\section{Ано т а ці я}

Лук'янииков Є. Д., Лук'янчикова В. Є. Криміналістична характеристика в методиці розслідування окремих категорій злочинів. - Стаття.

У статті аналізується поняття криміналістичної характеристики і структура їі елементів. Проведено порівняння та зіставлення характеристик злочину, які зустрічаються в наукових дослідженнях. Кожна наука намагається виділити й дослідити ті ознаки злочину та їх сукупності, що сприяють вирішенню завдань щодо розкриття злочинів і запобігання їм. Найбільш розробленими $€$ кримінологічна, кримінально-правова та криміналістична характеристики. Для організації та планування роботи з розкриття злочинів пропонується використовувати відомості про ознаки злочинів, що містяться як у криміналістичній, так і в інших характеристиках. Висловлено сумніви щодо можливості побудови кримінально-процесуальної й оперативно-розшукової характеристики злочину. Незважаючи на те що кримінальна процесуальна та оперативно-розшукова діяльність відбувається навколо злочину, сам він не є предметом дослідження цих наук. Для розробки рекомендацій із розкриття злочинів необхідно користуватися відомостями, що містяться в характеристиках, які розроблені на відповідному рівні та пройшли тривалу апробацію практикою.

Ключові слова: характеристика злочинів, криміналістична характеристика, методика розслідування, кореляційні зв’язки, алгоритмізація, прогнозування.

\section{Анн о т а ция}

Лукьянииков $E$. Д., Лукьяниикова B. E. Криминалистическая характеристика в методике расследования отдельных категорий преступлений. - Статья.

В статье анализируется понятие криминалистической характеристики преступлений и структура ее элементов. Проводится сравнение и сопоставление характеристик преступления, которые встречаются в научных публикациях различных отраслей юридической науки. В каждой науке стремятся выделить и изучить те признаки преступления и их совокупности, которые способствуют разрешению задач раскрытия и предупреждения преступлений. Наиболее разработанными являются криминологическая, уголовно-правовая и криминалистическая характеристики. Для организации и планирования роботы по раскрытию преступлений предлагается использовать сведения, которые содержатся в криминалистической и других характеристиках. Высказываются сомнения в плане построения уголовно-процессуальной и оперативно-розыскной характеристик преступления. Несмотря на то, что уголовно-процессуальная и оперативно-розыскная деятельность развиваются вокруг преступления, само преступление не является предметом исследования данных наук. Для разработки рекомендаций по раскрытию преступлений необходимо пользоваться сведениями (информацией), которые содержатся в характеристиках, разработанных на достаточном теоретическом уровне и прошедших соответствующую апробацию практикой.

Ключевые слова: характеристика преступлений, криминалистическая характеристика, методика расследования, корреляционные связи, алгоритмизация, прогнозирование.

\section{S u m m a r y}

Lukianchykov Ye. D., Lukianchykova V. Ye. The chriminalistic's characteristics are the element of methodology investigation of some types of crimes. - Article.

The concept of criminalistics description and structure of its elements is analyzed. Comparison of characteristics of crime, which are found in scientific investigation is made. Every science tries to select and investigate those signs of crime and their aggregate, which are instrumental in the decision of tasks from solving and prevention of crimes. The most developed characteristics are criminology, criminal law and criminalistics. It is suggested to use information about the signs of crimes, that is contained both in criminalistics and in other descriptions for organization and planning of work of solving of crimes. Doubts in relation to possibility of construction criminal procedure and operational-investigative characteristics of the crime are expounded. Despite the fact that criminal procedural and operational-investigative activities occur around the crimes it is not the object of the investigations. It is necessary to use information that is contained in descriptions that is worked out at corresponding level and passed the protracted approbation practice for development of recommendations for solving of crimes.

Key words: description of crimes, criminalistics description, methodology of investigation, cross-correlation connections, algorithmization, prognostication. 